\title{
MARÍA NEGRONI Y LA PUESTA EN ESCENA DE LO NO DICHO
}

ANDREA CASTRO

Göteborgs universitet andrea.castro@sprak.gu.se

RESUMEN: La obra de María Negroni se caracteriza por una puesta en diálogo entre géneros y medios desde la escritura. En este trabajo, focalizando en su poema largo La jaula bajo el trapo (1991) y en su novela La Anunciación (2007), se estudia cómo, a través de la representación de otros medios que exceden lo escritural, los textos activan la función conativa del lenguaje y convocan al lector a una posición de espectador, o sea, a asumir el rol del público de teatro ante un espectáculo. Este rol de lector-espectador le permitirá entrar en contacto, a través de una combinación de procesos cognitivos y percepción sensorial, tanto con el lenguaje como con lo no dicho, es decir con esos aspectos de la experiencia y de la memoria que no llegan a formularse con la palabra. A partir de los ejemplos analizados, se puede postular que los textos estudiados invitan a una reflexión, no solo de la limitaciones que presenta el lenguaje en cuanto a sus posibilidades de describir la experiencia, sino también acerca de las de la noción de sujeto y de la idea de subjetividad unitaria de base.

PALABRAS CLAVE: literatura argentina; poesía; intermedialidad; rol lector; subjetividad

ABSTRACT: The literary work of María Negroni constantly creates dialogues between genres and media. Focusing on her long poem La jaula bajo el trapo (1991) and her novel La Anunciación (2007), this article aims to analyse how the 
texts, through the written representation of other media, activate the conative function of language, summoning the reader to take the position of a spectator; that is, to assume the role of the theatre audience when viewing a performance. This reader-audience role will in turn open the possibility of, by a combination of cognitive processes and sensorial perception, getting in touch with those aspects of experience and memory that are never put into words. Through the analysed examples, the article postulates that the texts in question invite to reflect not only on the limitations of language as regards describing experience, but also on the notion of subject and the idea of a unitary subjectivity.

KEYWORDS: Argentine Literature; Poetry; Intermediality; Reader Role; Subjectivity

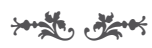

\section{Puesta en escena}

La obra de la argentina María Negroni se caracteriza por una puesta en diálogo entre géneros y medios desde la escritura -poesía, narrativa y ensayoen la cual siempre se nota un fuerte predominio de la función poética sobre otras funciones del lenguaje. El collage, el ready-made, las artes visuales y las colecciones son algunas de las obsesiones a las que vuelve la escritora.

En un trabajo anterior sobre el papel del arte figurativo cristiano del siglo xv en la novela La Anunciación (2007), me interesé por cómo el texto, a pesar de tratar sobre temáticas de memoria reciente, obstruye la posibilidad de una lectura mimética y referencial. Allí muestro cómo esto se logra a través de una discusión sobre el arte como promesa, como posibilidad de ir más allá de los datos históricos, y que postula "la verdad como idea que nos guía a nunca dejar de buscar en los resquicios de lo que ha quedado escrito en la Historia o representado en el 'teatro de la memoria'" (Castro 2015a: 179).

Pienso, no obstante, que la novela antes mencionada y, más aún, el poema La Jaula bajo el trapo (1991), ${ }^{1}$ proponen algo más. Con esto quiero decir que no solo plantean el arte como potencialidad, sino que también llevan a cabo una suerte de puesta en escena de diálogos y situaciones. Se trata de dos textos que a través del modo escritural incluyen otras dimensiones mediales en el acto de lectura, apropiándose de los recursos que ofrece el género dramático -el sonido, la luz, el movimiento, las imágenes, el espacio-. Quiero argüir que a través de un juego con la representación de la "matriz intermedial generadora de sentidos que es el espacio escénico" del teatro actual (Thenon 2013: 189), ${ }^{2}$

\footnotetext{
1 El libro fue primero editado por la Editorial Cuarto Propio, en 1991. En este trabajo, por recomendación de la misma autora, citamos por la edición de Ediciones La Palma, de 2014, para la que se hizo una revisión de erratas.

2 "La creación teatral actual es, por su naturaleza, de índole inter-artística. Buscas en consecuencia favorecer la aparición de condiciones propicias para un trabajo intermedial. En él entran en relación transformadora los diferentes lenguajes de la acción artística, encausados en una espacialidad espectacular común. La palabra poética, el cuerpo presencial o virtual, la arquitectura
} 
los textos activan la función conativa del lenguaje, convocando al lector a una posición de espectador, esto es, a asumir el papel de público de teatro ante un espectáculo. Este rol de lector-espectador le permitirá entrar en contacto, a través de una combinación de procesos cognitivos y percepción sensorial, tanto con el lenguaje como con lo no dicho, es decir, con esos aspectos de la experiencia y de la memoria que no llegan a formularse con la palabra. Desde una perspectiva fenomenológica, podemos plantear estos textos como intentos de escenificar los fenómenos según existen en la conciencia del sujeto. En esta tanto palabras, como cosas y sensaciones significan, integrándose en nuestro saber de la realidad, saber que nos ayuda a entender nuestra particular "percepción del mundo como aquello que funda para siempre nuestra idea de la verdad" (Merleau-Ponty 1993: 16).

Puede ser necesario subrayar que el planteamiento del presente trabajo no está aludiendo al dialogismo de Bajtín cuando este, por ejemplo, anota: “¿No es siempre todo escritor (incluso el más puro poeta lírico) un dramaturgo en la medida en que distribuye todos los discursos entre voces ajenas, incluida la imagen del autor (así como las otras personas del autor)?" (citado por Scarano, Romano y Ferrari 1994: 27). Sin negar la importancia de las voces en la obra de María Negroni, mi propuesta apunta a visualizar el trabajo que hace la autora a través de la representación de otros medios que exceden lo escritural más allá de su utilización de voces discursivas, y cómo el texto invita al lector a un compromiso casi diría físico por activar los diferentes sentidos -al menos en la imaginación y quizás también en el cerebro ${ }^{3}$ - en el acto de lectura.

En este sentido, como lo advierte Jacques Rancière, debemos tener cuidado de pensar los individuos sentados ante una puesta en escena, en una aparente distribución de roles previa, como "alegorías encarnadas de la desigualdad" (2010: 19). Por el contrario, voy a argüir que, a través de la lectura, los textos estudiados nos ayudan a entender que las "oposiciones -mirar/saber, apariencia/realidad, actividad/pasividad- son todo menos oposiciones lógicas entre términos bien definidos" (2010: 19). Antes bien, ofrecen al lector caminos para experimentar el texto y lo que este representa, tanto cognitivamente -a través de procesos mentales e intelectuales- como físicamente -a través de procesos emocionales y sensoriales-. De este modo, el lector podrá entrar en contacto con las palabras -en sus diversas calidades: gráfica, semiótica, semántica, pragmática- y también, con lo que queda entre ellas, por ejemplo, en los silencios, la música y las relaciones entre diferentes medios que ocupan el espacio cuando las voces se callan.

\footnotetext{
sonora, la construcción escenográfica, la imagen tecno-visual, los lenguajes musicales y sonoros, los universos acusmáticos, las escrituras gestuales en el espacio, actuando en conjunto desde esa matriz intermedial generadora de sentidos que es el espacio escénico, supone una integración de los códigos y una interrelación de las distintas trayectorias poéticas a partir de figuras sensoriales, concepto artístico que se aparta considerablemente de los modelos dramáticos tradicionales" (Thenon, 2013: 188-189).

3 Desde la perspectiva de la neurociencia cognitiva, cabe suponer como hipótesis que un estudio de la actividad electroquímica de individuos leyendo los textos aquí estudiados mostraría una marcada activación de las áreas visual, auditiva, somatosensoriales, etc.
} 
En el poema La jaula bajo el trapo (2014) se escenifica un diálogo mental entre una hija, su madre y su memoria. María Moreno, en la nota de presentación del libro en el sitio web de la editorial la compara con Et l'une ne bouge pas sans l'autre (1979) de Luce Irigaray:

Negroni hace gala, en este largo poema de amor, de una distancia samurái, oponiendo a la lírica intrauterina de Luce Irigaray en Jamás la una sin la otra (también teatro entre una mujer y su madre) la meticulosa puesta en escena [mi énfasis] de una tragedia que nunca se desencadena; a la disputa ensordecedora de los divanes, el protocolo y las condiciones de la disputa misma; a un erotismo sin quién es quién, el ascetismo de dos cuerpos cuidadosamente separados por la vestimenta y el discurso, como si se deseara hacer patente lo que, en el corazón de la etiqueta, permanece de la violencia que se intenta mensurar. (Moreno 2015)

La comparación es válida porque si en Irigaray nos encontramos ante una voz solitaria que se expresa a través de un monólogo interior desprovisto de espectadores, el poema de Negroni no solo incorpora la voz de la madre en el diálogo con la hija, sino que, como pretendo mostrar, incluye otras dimensiones mediales en el acto de lectura.

La novela La Anunciación se construye como una combinación de distintas series de diálogos que, a modo de montaje, van iluminando los temas sobre los que discurre la narración desde la conciencia de la narradora autodiegética en Roma en la primera década del siglo xxı. Hay tres series que serán particularmente interesantes para este trabajo. En primer lugar, me refiero a los diálogos entre la narradora y Humboldt, ${ }^{4}$ su amante desaparecido en marzo de 1976. En segundo lugar, a los diálogos entre diferentes aspectos de la militancia política a través de voces con nombres que se escriben casi siempre con minúscula: el alma, la palabra casa, el ansia, lo desconocido, Nadie. ${ }^{5}$ En tercero, al diálogo entre la protagonista y el monje Athanasius.

A continuación, se mostrará cómo se manifiesta en los textos lo que he llamado la puesta en escena de lo no dicho.

\section{LA JAULA BAJO EL TRAPO O EL DESPLIEGUE DE LO ESCÉNICO}

En La jaula bajo el trapo, recurriendo a un repertorio de los medios que entran en juego en el escenario teatral actual, el texto despliega ante el lector un

\footnotetext{
${ }^{4}$ Humboldt es el nombre de guerra del amante y compañero de militancia de la narradora. En ningún momento se explica por qué se llama Humboldt y nunca se lo menciona con otro nombre que ese. (Esto mismo pasa con Emma, la pintora, amiga y también compañera de militancia). La inevitable connotación histórica que nos remite a los hermanos Alejandro y Guillermo, el primero conocido por sus viajes por el continente americano y el segundo por sus reflexiones sobre la educación y sobre el lenguaje, no se explicita en la novela. No obstante, si consideramos la importancia del coleccionista, matemático y egiptólogo Athanasius Kircher en relación con la conformación de una superposición temporal en la novela, los hermanos alemanes agregarían una capa de tiempo más y Alejandro Humboldt, en su labor antropológica y de coleccionista, sería otra pieza en el afán colector de la poética de la autora.

5 Sobre los nombres de las voces ver también Bocchino (2011: 103) y Castro (2015b: 176).
} 
espacio escénico en el cual se representarán diferentes situaciones y sensaciones. Podemos especificar la variedad de medios o, en palabras de Thenon (2013: 189), "los diferentes lenguajes de la acción artística" con el pasaje antes citado: "[L]a palabra poética, el cuerpo presencial o virtual, la arquitectura sonora, la construcción escenográfica, la imagen tecno-visual, los lenguajes musicales y sonoros, los universos acusmáticos, las escrituras gestuales en el espacio" (Thenon 2013: 189).

Desde el inicio, la voz poética asume un rol de dramaturga al introducir una situación escénica a través de lo que entendemos como una didascalia o acotación. Esta pone en acción la función conativa de la lengua, invitando al lector a ocupar un lugar en la butaca de un teatro imaginario -que de hecho nunca se menciona en el texto- y a activar en su imaginación los sentidos de la espacialidad, la visión y el oído:

penumbra

madre e hija

ambas están sentadas, expresión ausente, melancólica más bien.

Y unos versos más adelante:

... de la cabina del operador de luces, ubicada en el centro del escenario, salen las notas que se intercalan en el discurso de la hija, se oyen como si fueran emitidas por la radio, en un registro liviano, impersonal. (Negroni 2014: 9)

Así, desde los primeros versos, se introduce la palabra poética, también en su materialidad: las grafías dispuestas de una cierta forma sobre la página. Simultáneamente, a través de la palabra, el texto evoca otros medios como los cuerpos de los personajes, la iluminación -"penumbra"-, y el sonido -que podría calificarse de acusmático (Chion 1999), dado que, aunque se sugiere que puede salir de una radio, se oye sin ser visto-. La escena no es silenciosa, sino que además de la música arriba evocada, hay voces. O mejor dicho: una voz porque "[a]unque a veces pareciera oírse la voz de la madre, es la hija quien habla (la voz interior no es monólogo)". Es la de la hija, y se la describe con minucia: "Su tono de alertas, barcos en guardia, banderas, casi nunca degenera en sermón. Jamás en lirismo. [...] se confiesa como una codicia de algo" (Negroni 2014: 9).

La voz aparece en su materialidad. Más allá de las palabras, es el tono el que resalta y significa. El sonido se representa así como signo. De modo análogo a la supuesta radio en la cabina del operador, el cuerpo de la hija será el medio de transmisión de ese sonido, dándole entonces singularidad: una singularidad, señala la filósofa Adriana Cavarero (2005: 13), encarnada en un cuerpo. Y es que Cavarero nos recuerda algo en apariencia obvio: cuando la voz humana vibra, hay alguien de carne y hueso que la emite (2005: 4). De este modo, con su tono y su timbre particulares, la voz de la hija se convierte en un llamado a un interlocutor, es decir, a la presencia de otros cuerpos únicos que la incorporen a sus conciencias y entablen un diálogo con ella. 
A lo largo del poema, la voz poética-dramatúrgica, entrelazará sus didascalias con el diálogo entre hija y madre. Este último, si bien tiene lugar en la conciencia de la hija, a la vez se despliega en esta suerte de escenario que, como quiero mostrar, mantiene al lector en un lugar de espectador.

Continuando con el aspecto de la voz, podemos detenernos en la siguiente escena en la que aparece el cuerpo mudo de una niña. La página que introduce y contiene la escena completa se ve así:
Aparece una niña en camisolín de penas. Ojazos. Tiene un pañuelo en la mano. Las rodillas peladas. Le sangra la nariz.
"Nadie evoca impunemente el tiempo de la infancia" (Kántor) Se oyen voces en off. Juegos. Movimiento. La niña salta frenética a la cuerda.
El vacío se compensa con el aspaviento. (Negroni 2014: 23)

El cuerpo de la niña entra a ocupar la imagen que se construye como un escenario -"Aparece una niña". En un primer momento, se queda quieta, y podemos imaginarla en el centro del escenario. Esto nos permite observarla mientras la voz poética la describe de una manera escueta pero efectiva. Asimismo, la quietud crea un punto de inicio que amplificará lo frenético de los movimientos de la niña al final de la página -o al final de la escena en ella representada-.

Es de notar que el cuerpo que se ha puesto en movimiento no emite ningún sonido. El sonido de la escena viene de voces en off, de juegos y de movimiento. No obstante, el movimiento de la niña no se describe como lúdico sino que el adjetivo 'frenético' habla de uno más bien desquiciado, y que al ocurrir en silencio crea un vacío ominoso. No se puede evitar percibir que hay algo que las voces en off, en su aparente alegría juguetona, subrayan como faltante. El cuerpo de la niña saltando a la soga en su camisolín se recorta contra ese sonido de fondo y el movimiento cobra una función equívoca: ¿quiere ocultar algo o quiere llamar la atención sobre algo no dicho? O tal vez quiera llamar la atención sobre sí mismo, sobre el lenguaje mudo del cuerpo, ese cuerpo que se muestra en toda su inmanencia, evitando ocultarse detrás de, como decía Walter Benjamin en otro contexto, "la palabra como medio, la palabra vana, el abismo de la charlatanería" (1998: 72).

La cita atribuida a Kántor ${ }^{6}$-"Nadie evoca impunemente el tiempo de la infancia"- corta la escena en dos. Entre la parte de la quietud y el silencio y la del

\footnotetext{
6 Es esta la única vez que el nombre de este artista aparece en el poema y es de notar que aparece con tilde sobre la 'a'. En una semblanza sobre Bruno Schultz fechada en el año 2009, Negron menciona "La clase muerta" de Tadeusz Kantor y en esa ocasión no usa tilde (Negroni 2009). Esta es la forma corriente de escribir el nombre de Kantor en castellano. Podemos preguntarnos si la tilde en el poema es una errata o si es intencional. Si fuera intencional se podría pensar como estrategia o bien para asegurarse de que el acento recaiga sobre la 'a' y así mantener un control sobre el ritmo del poema; o bien como un juego entre la realidad y la ficción, otorgándole al nombre una calidad de máscara dentro de la escena teatral, diferenciándolo del Kantor de carne y
} 
movimiento hay un Ilamado a lo textual: las palabras entre comillas. El recurso de la cita es omnipresente en la obra de María Negroni, haciendo de sus textos espacios errantes, cargados de voces de poetas y de artistas. En este sentido, no hay duda de que también son textos dialógicos en la acepción bajtiniana. Pero como ya se aclaró antes, no es este el foco que me interesa seguir en este trabajo.

Desde una perspectiva intermedial, quiero proponer que la cita transforma la imagen en una suerte de emblema, anclándola en la tradición que se inicia en el siglo xvı. ${ }^{7}$ Tradicionalmente, esta composición constaba de tres elementos: el título, la imagen y el epigrama. Sugiero que la cita aquí atribuida a Tadeusz Kantor funcionaría como título. Según lo explica Juan Carlos Guerrero al describir las partes del emblema en su orígenes, el título, que era considerado el 'alma' del mismo y como tal solía estar arriba, era "una sentencia o dicho agudo y perspicaz, y, sin embargo, muchas veces críptico, escrito casi siempre en latín $y$, en algunos pocos casos en griego, que retomaba expresiones y/o afirmaciones de los clásicos, de la Biblia o de los padres de la iglesia" (Guerrero 2010: 124). El estatus de título en la página que nos ocupa estaría dado tanto por el hecho de aparecer entre comillas como por su formato de sentencia, sin duda algo críptica. El director de teatro y artista polaco ocupará en este caso un lugar junto a los clásicos, la palabra bíblica o los padres de la iglesia. No obstante, en lugar de ir arriba de la imagen, las palabras de este padre del teatro actual y de la performance quedan entrelazadas con las imágenes. Así, evocan sus propias y legendarias puestas en escena, ocupadas no sólo con la representación de la memoria, sino también con la destrucción de las jerarquías que dominan a las narrativas tradicionales.

Podemos pensar entonces que mientras las palabras de Kantor evocan una estructura emblemática, al mismo tiempo subvierten la jerarquía de dicha estructura, poniendo la imagen en el centro y dejando que sea esta la que abraza - ¿y abrasa?- las palabras. Si bien su figura, y lo que esta representa estéticamente, es elevada a calidad de clásico, sus palabras, al igual que el tono de la hija al principio del poema, no "degenera[n] en sermón" (Negroni 2014: 9) como el que se esperaría de un padre de la iglesia. Antes bien, se muestra como padre del arte, uno que invita a unir fragmentos dispares y diversos, a combinar medios, a hacer coexistir a vivos y muertos. ${ }^{8}$

Otro ejemplo de la función de las didascalias en relación con el uso de la voz para la construcción de un espacio escénico, lo encontramos en el siguiente

\footnotetext{
hueso. Esto último nos recuerda el juego de Michel Lafon cuando escribe Pierre Ménard con tilde en su novela Une vie de Pierre Ménard para así diferenciarlo del Pierre Menard ficticio de Borges (sin acento), remitiendo al supuesto Pierre Ménard histórico -desde ya, igualmente ficticio.

7 El diálogo con la pintura y las artes plásticas es un elemento recurrente y central en la obra de María Negroni.

${ }^{8}$ Sobre el teatro de Kantor apunta Isabel Tejeda: "Un teatro que se nutre de las múltiples contaminaciones y recursos que recibe de otras disciplinas no escénicas y que, en este momento concreto, funciona como paradigma de su fructífera dispersión creadora y de las relaciones simbióticas entre su obra teatral y su obra plástica" (2002: s.p.).
} 
diálogo entre una voz $n^{\circ} 1$ y una voz $n^{\circ} 2$, las que, como coro de tragedia griega, comentan la 'acción':

voz $n^{\circ} 1$ - Algo irrumpe en la jaula: la sangre, este texto. El encierro es promiscuo. ¿Oís cantar a la muda? Eso, tal vez, podría salvarnos.

voz nº 2 - (distante) Está por verse. El canto es imperfecto. (Negroni 2014: 38).

Es un diálogo circular en el cual la voz n 1 se esfuerza por escuchar algo, por hacer sentido del cuerpo mudo -"¿La oís cantar?" "¿Qué dice?"-, mientras la voz $\mathrm{n}^{\circ} 2$ insiste en negar todo sentido -"no tiene sentido" "el canto es imperfecto"-. Hacia el final de la página, un paréntesis a modo de acotación, aclara que:

(Este diálogo o imposibilidad de diálogo se reitera una y otra vez, aparece y desaparece como si alguien - afuera de la escena- accionara un playback frenético. La eternidad tiene la belleza de las obsesiones.). (Negroni 2014: 38)

De este modo, la voz poética o dramatúrgica, al ubicarse al final de la escena, obliga al lector a ajustar el horizonte (Iser 1980: 99-103) y entender el diálogo como un efecto mecánico y acusmático. Estamos antes voces desprovistas de cuerpo, que no solo llaman la atención sobre el lenguaje del cuerpo de la hija, sino también sobre la materialidad del texto al ponerlo a la par de la sangre (el cuerpo). Ambos irrumpen en el espacio cerrado de "la jaula", dice la voz $\mathrm{n}^{\circ} 1$, y nos remite al título de la obra al que el poema vuelve hacia el final, cuando la hija dice:

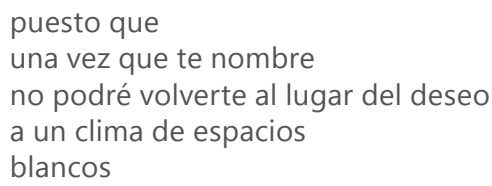

El espacio de la jaula en el que irrumpen el texto y la sangre es un "espacio blanco", un espacio en blanco: es el silencio de lo no dicho que la hija teme exponer, diluyendo el deseo y la libertad de "la cosa" al nombrarlo. En este contexto, es relevante remitir a una cita de La pasión según $G$. H. de Clarice Lispector, escritora con la cual Negroni entra en diálogo en varias ocasiones: "el nombre es un añadido, e impide el contacto con la cosa" (1982: 149). La irrupción del texto y la sangre en dicho espacio es percibida por la hija como peligrosa porque, como dice la voz poética en otra parte del poema:

Lo no dicho aún es silencio.

¿Perderá esa libertad? (Negroni 2014: 39) 
Así, el deseo y la libertad se ubican en un espacio interior como el que describe Merleau-Ponty cuando anota: "una cosa no se da efectivamente en la percepción, es recogida interiormente por nosotros, reconstituida y vivida por nosotros en cuanto vinculada a un mundo" (1993: 340). Es decir, la cosa es incorporada al sujeto y vivida por este, quien la entiende a partir de su conocimiento del mundo. Naturalmente, este conocimiento se va modificando con el tiempo de vida. Al estar incorporada a nuestro cuerpo, a nuestra conciencia, a nuestra vida, ni la cosa es un "objeto como en sí" ni la conciencia es "pura conciencia" (Merleau-Ponty 1993: 335)..$^{9}$ El nombrarla sería entonces fijarla, transformarla en un "objeto como en sí". Según estas reflexiones, podemos entender el escenario ficticio alrededor del cual el texto nos convoca como una invitación a presenciar la lucha entre el deseo de entender a través de la experiencia y el temor a perder ese espacio en blanco, a la palabra que objetiviza la experiencia y la vacía.

Otros tipos de didascalias son las que recurren a efectos de iluminación. Un ejemplo lo encontramos en la escena que empieza con un "BLACKOUT" y termina con "Los círculos blancos de los reflectores [que] no saben dónde posarse" (2014: 19). Invocando al sentido de la vista, esta escena materializa lo no visto. Al explicar que los personajes han desaparecido "como si se hubieran perdido en el tiempo, o en sí mismos" (2014: 19), la voz dramatúrgica parece hacer alusión al aspecto abstracto e inaprehensible de la memoria subjetiva o individual. Dentro de este razonamiento no podemos dejar de mencionar que la noción de blackout no solo remite a un efecto de iluminación en un escenario teatral, sino también a un estado mental de pérdida momentánea de la memoria de la cual el sujeto tiene una cierta conciencia. De este modo, la falta de luz en un sentido material -sobre un escenario- queda estrechamente ligada a una memoria que es consciente de sus agujeros, de sus faltas.

Teniendo en cuenta este doble sentido de la palabra blackout -que con su tipografía en letra de molde y cursivas señala un protagonismo en la página-, las palabras que vuelan por el escenario "rompiendo el equilibrio [...] de la nada", se pueden entender como palabras-objetos, buscando iluminar la oscuridad, abrir algún resquicio en la nada que es la falta de memoria. Asimismo, hay una melodía que se describe como invisible, lo cual puede entenderse como un elemento acusmático o bien como una suerte de sinestesia en negativo. Y digo 'en negativo' dado que siendo invisible, no puede activar el sentido secundario de la vista en lugar del sentido del oído -que sería el sentido primario al que apela la música-. También hay elementos invisibles en los bordes escénicos: "En los bordes escénicos, si hubiera luz: edificios espejados, una fotografía de Jean Harlow" (Negroni 2014: 19). La voz los menciona, trazando así un esbozo de écfrasis de lo invisible. Lo no captado por la mirada también existe, nos recuerda la voz autoral, y el proceso de percepción es aleatorio. Los reflectores -"los círculos

\footnotetext{
9 Otra cita del filósofo francés que puede servir para profundizar en su razonamiento: "La experiencia de la cosa es, primero, en su evidencia, y toda tentativa por definir la cosa, ya sea como polo de mi vida corporal, ya sea como posibilidad permanente de sensaciones, ya sea como síntesis de las apariencias, sustituye la cosa, en su ser originario, con una reconstrucción de la cosa por medio de fragmentos subjetivos" (Merleau-Ponty 1993: 339).
} 
blancos"- al final de la página "no saben dónde posarse". Como el rayo de la mirada, donde quiera que se posen marcarán una diferencia entre la experiencia perceptual y lo que queda fuera de ella pero no por eso deja de existir.

La luz y la imagen también entran en juego con las palabras y con el sonido a través de una página que en su totalidad se puede leer como didascalia:

Diapositivas proyectan el cuerpo de los personajes sobre el cuerpo de los actores. O una casa de la infancia sobre dibujos de esa casa.

Debajo de las imágenes, se pondrán, entre paréntesis, algunas palabras: yo, hace ya tiempo, la madre. Una inscripción rezará: ESTO ES VERÍDICO.

Se oyen sollozos que partirían el alma. (Negroni 2014: 30)

En esta escena, cuerpos y casas se superponen, revelando niveles diegéticos ficticios que sin embargo no se encuentran separados: personajes, actores, casa de la infancia y la misma casa dibujada. Imágenes múltiples cuya rúbrica, entre paréntesis, puede entenderse como un intento de aunar la dispersión del sujeto -en la memoria, en la representación- bajo un pronombre o sustantivo -"yo", "la madre" (no mi madre) - o de las memorias de la infancia bajo un marcador temporal que indica su existencia al menos en el pasado -"hace ya tiempo"-. La inscripción en letras de molde invita a pensar qué es lo verídico: ¿lo que se puede ver/fotografiar/dibujar? ¿lo que lleva rúbrica? Los sollozos Ilenos de dolor -"que parten el alma"- que se anotan al final de la página, pueden entenderse o bien como resultado de la inscripción final, o bien como sonido de fondo a lo largo de toda la escena. En ambos casos, el llanto puede estar expresando el dolor del deseo o de la libertad perdidos en aras de lo verídico, lo que ha quedado dentro del logos.

No obstante, es necesario resaltar que en muchos casos, las didascalias o sus posibles lecturas no son tan concretas como las de los ejemplos hasta acá presentados, sino que se alejan de lo figurativo, evocando así una lectura poética en la cual el escenario pierde consistencia, y estableciendo un juego entre lo visible y lo visual.

George Didi-Huberman explica lo visual como el intento de la tradición figurativa cristiana de escapar del orden del mundo visible y del orden clásico de la imitación (2003: 21), para buscar otros caminos hacia la verdad esencial de los objetos (2003: 31). Así, por ejemplo, podemos volver a una de las escenas ya estudiadas que termina con la frase "(La eternidad tiene la belleza de las obsesiones)" (Negroni 2014: 38). De estructura semejante a la cita de Kantor antes comentada, esta suerte de sentencia saca al lector de su posición de espectador y lo trae de vuelta a la página, a las palabras sobre la página, y a una búsqueda de sentido que no radica en lo que se ve o se deja de ver sobre el escenario. Así, el diálogo de voces que se repite mecánicamente adquiere nuevos sentidos tras la lectura de esa última frase. 
Asimismo, podemos detenernos en la siguiente acotación cuya descripción no sirve para visualizar un espacio concreto sino más bien funciona como conjuro de otro tipo de espacio más allá de lo visible:

Una escenografía improbable, de bordes filosos.

Perímetros, algunas formas livianas, una bailarina, una copa.

Los objetos se instalan, proliferan, se disponen a la nuli-

dad, al sentido reducido de un adorno. (Negroni 2014: 34)

A ambos tipos de didascalias hay que agregarles las partes del poema que constituyen el diálogo interior de la hija con su madre. Como, por ejemplo:

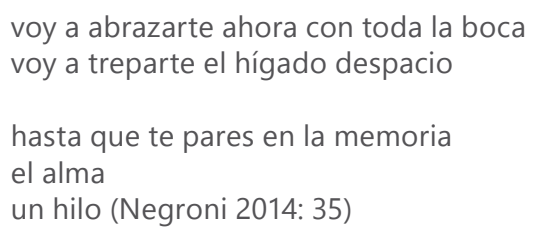

La voz de la hija habla a su madre, la conjura en su interior, la amenaza, la busca en su memoria como en un laberinto. El alma le sirve como hilo de Ariadna. Pero a diferencia de Teseo, la hija no saldrá victoriosa del laberinto, sino que tendrá que comprender que:

solo en la renuncia a la luz

algo encontrará su forma (Negroni 2014: 67)

Hacia el final de La Anunciación, aparece la idea del "pliego blanco" (2007: 225), así lo comento en un trabajo anterior:

La memoria se presenta, por tanto, como una actividad de excavación arqueológica (Didi-Huberman 2011: 116), pero no de cuerpos materiales, sino de voces, de sensaciones, de experiencias. Sin embargo, cada intento de exhumación destruye la potencialidad de lo hasta el momento silenciado. Solo el pliego blanco, en su pura potencialidad, guarda la promesa de una posibilidad de darle lugar al deseo, a los silencios y a los olvidos. (Castro 2015a: 179)

El poema de Negroni, a través de una puesta en escena de los contenidos de una conciencia, entre los que resalta lo no dicho y lo invisible, apela a la conciencia de sus lectores como espacio en el que lo no dicho también pueda existir. Al recurrir a la idea de la renuncia a la luz, a la jaula bajo el trapo, a los espacios que los reflectores no logran iluminar si bien están ahí, el texto puede también funcionar como invitación a incorporar esta experiencia lectora/espectadora, incorporar la noción de lo no dicho también como una verdad que sin duda cuestionaría la verdad objetiva de la ciencia. 


\section{La ANUNCIACIÓN Y EL GABINETE DE RETAZOS DE VIDA}

En La Anunciación, los diálogos entre Humboldt y la protagonista ${ }^{10}$ vienen desprovistos de detalles escénicos y pueden verse, al igual que la serie de aquellos entre Humboldt y los demás compañeros de militancia ${ }^{11}$, como meros diálogos en un texto narrativo. Sin embargo, hay un detalle que apunta en la dirección de una puesta en escena del tipo que se viene discutiendo: todos terminan con una referencia a un trozo musical que los acompaña, introduciéndose así un efecto intermedial que apela a activar en el lector el sentido del oído. La formulación es la misma en todos los casos, si bien introduciendo uno diferente cada vez. La primera vez dice así: "La música que corresponde a esta escena es $A$ Cure for Pain, de Morphine" (Negroni 2007: 33). Los demás son: Pulses, de Steve Reich (86), Danse gothique pour la tranquillité de mon âme, de Eric Satie (109), Story, de John Cage (136), Orfeo Fragmenter, de Bo Holten (187) y Pas sur la neige, de Debussy (208).

Dada la linealidad del acto de lectura -al menos en una primera fase- es significativo que la referencia al trozo musical se introduzca al final del diálogo. De este modo, la referencia obliga a un marcado ajuste del horizonte establecido hasta el momento, de modo que la referencia musical, como en un proceso de edición a posteriori, agrega una banda de sonido a los diálogos particulares. A la vez, se pueden entender como variaciones de temas particulares contenidas en la escena en la que están incluidas o en el libro como totalidad.

Por ejemplo, el último diálogo de la serie se inicia con la pregunta de la narradora-protagonista: "¿Por qué íbamos a dar la vida, Humboldt?" (2007: 207). Humboldt le habla de participación, de querer quedar dentro de la Historia y la remite a libros de teoría política, de tácticas y estrategias: "leé bien, buscá más bibliografía", la incita, y le dice estar contento porque "fue necesaria esta hecatombe para que me encontraras." Sin embargo, como los pasos sobre la nieve del fragmento de Debussy que corresponde a la escena, la narradora dice: "Pero no te encontré. No quedó nada en la plataforma de la muerte. Nadie supo decirme dónde se incrusta la vida cuando ya nadie la habita" (2007: 208). Así, la voz narrativa vuelve sobre uno de los temas de la novela: las experiencias que no quedan registradas en los libros, en la Historia a la que Humboldt hace alusión. A su vez, la nieve introduce el tema de la página en blanco, de la potencialidad siempre frágil ante el lenguaje pero también siempre existente.

De este modo, quiero resaltar que el trozo musical cobra una suerte de efecto divergente sobre la palabra escrita y su capacidad de narrar, sacándole protagonismo y dando lugar, a través de otra modalidad, a la experiencia de la narradora de que el sentido que ella busca no se encuentra meramente a través de la escritura, porque hay algo que se escapa entre las palabras.

\footnotetext{
10 Por ejemplo, en la dedicatoria que se encuentra al principio del libro: "A Humboldt que vive todavía en las palabras no escritas" y "No sé cómo se cuenta una muerte, Humboldt" (Negroni 2007: 13).

11 Por ejemplo, en Negroni (2014: 33-34 y 36-37).
} 
Por otro lado, en la otra serie de diálogos, aquella entre "las voces con nombres como máscaras: el alma, la palabra casa, el ansia, lo desconocido, Nadie" (Castro 2015a: 178), no hay didascalia alguna. Esta sí es una serie de diálogos que podrían perfectamente entenderse como tradicionalmente narrativos. No obstante, quiero sugerir que estas voces, al comentar y discutir diferentes aspectos de la historia de la narradora protagonista, de sus sentimientos o de su búsqueda, pero asimismo de la narración, cumplen la función de coro de drama griego. Por ejemplo, esto se da a través del uso de comentarios metanarrativos o metalingüísticos:

\footnotetext{
"Anoche tuve un sueño horrible," insistió el ansia que odiaba las simplificaciones. "Soñé que llegaba mi madre a visitarme, trayendo un video. El video era azul y mostraba imágenes de Roma. [...]".

"Respirá hondo", intervino lo desconocido.

"¿Y si llamamos al alma? No debe andar muy lejos", propuso la palabra casa. "¿Te parece? ¿No será demasiado tarde? Ya estamos en la página 61". (Negroni 2007, 61)
}

Podemos observar el registro coloquial que le da inmediatez al diálogo, apelando así a una situación de oralidad que también contribuye a convocar a un lector espectador.

Este recurrir a otros medios y modalidades que juegan con desbordar el alcance de lo que pueden decir las palabras sobre el papel, sería una forma más de pelearse "con el sentido de lo que dicen los objetos escriturales" (Bocchino 2011: 104). Contribuyendo a esta lectura, en uno de los diálogos con Humboldt la narradora expresa: "Quiero que todo estalle, que el lenguaje deje ver la mugre, la baba, el pantano" (2007: 146). Recordemos la alusión a Tadeusz Kantor en La jaula bajo el trapo y su estética de los retazos, de introducir lo grotesco, lo bajo en sus representaciones, ya fueran escénicas, textuales o pictóricas. Así, también en este texto que tiende a lo narrativo -sin dejar de tener un fuerte tinte poético- hay, como en toda la obra de Negroni, una expansión del lenguaje hacia lo intermedial, con la introducción de lo visual, lo auditivo, lo táctil.

Un personaje central en esta idea de la puesta en escena es el monje Athanasius que hace de interlocutor de la narradora en sus merodeos por Roma. Athanasius, que se caracteriza por su ubicuidad y por su constante observación del mundo, aparece y desaparece por las calles romanas y ha sido testigo de los sucesos de abducción y muerte de los compañeros de la narradora en la calle Uruguay, en una ciudad de la Argentina de 1976. Así, se pone a la par del lector, quien tampoco puede más que observar el horror que las palabras despliegan ante sus ojos. Athanasius hace constantes referencias a su Museo del Mundo (Negroni 2007: 18), un gabinete de maravillas que el Atanasio Kircher histórico creó a lo largo de su vida como monje jesuita en el Colegio de Roma a mediados del siglo XVII, y que el personaje sigue construyendo en el presente de la narración. Recordando la superposición y combinación de elementos en algunas de las escenas de La jaula bajo el trapo, Athanasius tiene en su museo: "Acorazados, obeliscos, masacres, conciertos de animales, jeroglíficos, concep- 
ciones de Dios, trompos, juegos de té, circos, listas de pescados, plagas, sombras chinas, ambiciones, zootropos, viajes alrededor del mundo, dictadores, buzos, bicicletas sin manubrio..." (2007: 19).

También Emma, la amiga desparecida de la narradora, vive ahí. Así, el Museo de Athanasius se presenta como gabinete de trozos de realidad y de historia que al encontrarse en contextos novedosos y entrar en variedad de combinaciones abren a una potencialidad de lecturas de una realidad en la que, como explica el monje, "cada vida es todas las vidas, cada tiempo todos los tiempos" (2007: 20). Así también es la conciencia: un Wunderkammer que a su modo particular incorpora el mundo $y$, a través de "un proceso de integración en el que no se copia de nuevo, sino se constituye, el texto del mundo exterior" (Merleau-Ponty 1993: 31), lo contiene.

\section{EsPACIO TEATRAL Y REALIZACIÓN DE UNA VERDAD}

A lo largo de este trabajo, vengo discutiendo y argumentando que en los dos textos estudiados, María Negroni recurre a diferentes dimensiones mediales para convocar al lector, llevándolo a una posición de espectador. Esta implica activar no solo la mirada sino otros sentidos y sensaciones para lograr una combinación de lo cognitivo y lo sensorial en la conformación mental de las representaciones que se despliegan en el poema o en la narración. De este modo, como ya postulaba, el lector, al aceptar las reglas de juego propuestas por los textos, se percata de que oposiciones como "mirar/saber, apariencia/realidad, actividad/pasividad" no son "oposiciones lógicas entre términos bien definidos" (Rancière 2010: 19). Así, al activarse como espectador, "también actúa, como el alumno o como el docto. Observa, selecciona, compara, interpreta" (Rancière 2010: 19). Se puede pensar esta invitación a lectores-espectadores como una invocación a la intersubjetividad del espacio teatral que no presentará "el reflejo de una verdad previa, sino [...] una realización de una verdad" (Merleau-Ponty, 1993: 20) y no de la verdad.

Así, de manera análoga al espectador del teatro actual según Thenon, el lector-espectador que aquí propongo quedaría liberado "de una posible reacción emotiva preconcebida o de una recepción que intelectualmente intente dar sentido a la obra" (Thenon 2013: 186). Es decir, la función conativa activada por el recurso de la didascalia en los textos de Negroni, no apela a una acción determinada, sino a una activación de sentidos y sensaciones ante el texto, a experimentar el texto. Esto favorecerá la percepción de las combinaciones y configuraciones propuestas para, más que elaborarlo intelectualmente logrando una comprensión de lo leído, experimentar sensorialmente los espacios que se abren entre las palabras, logrando establecer relaciones no siempre calculadas o esperadas entre la conciencia representada y la propia conciencia de ese lectorespectador.

A partir de la discusión llevada a cabo se puede entonces postular que los textos estudiados invitan a una reflexión, no solo de las limitaciones que presenta el lenguaje en cuanto a sus posibilidades de describir la experiencia, sino 
también acerca de las de la noción de sujeto y de la idea de subjetividad unitaria de base. ${ }^{12}$ En los ejemplos dados, se fue mostrando que el yo de las obras de Negroni se hace con retazos de otros yo, con citas, con miradas, con oídos, con música. Es un yo que tiene incorporado el mundo. Consecuentemente, al darle cabida a la potencialidad intermedial del escenario teatral, los textos abren a una subjetividad nómada, fluida, que se transforma según diferentes figuraciones en el sentido que les da Rosi Braidotti (2003; 2005): una subjetividad que nunca es sola o fija ante sí misma o ante la Historia, sino que se construye performativamente en los puntos de encuentro con otras subjetividades, otros espacios, otras tecnologías. Desde la intimidad primera de la relación con la madre en La jaula bajo el trapo -la primera figuración de la que somos parte como seres vivientesa la búsqueda en los resquicios de la memoria en La Anunciación-que siempre es memoria en relación con otras personas y en otros espacios- los textos de Negroni, al invitar al lector a proyectarse en una suerte de espacio teatral o dramatúrgico, crean encarnaciones de la conciencia de un sujeto siempre inmerso en redes fluidas, nunca individual y fijo.

\section{OBRAS CITADAS}

Benjamin, Walter (1998): "Sobre el lenguaje en general y sobre el lenguaje de los hombres". En: Para una crítica de la violencia y otros ensayos. Iluminaciones IV. Trad. Roberto J. Blatt Weinstein. Madrid, Taurus, pp. 59-74.

Bocchino, Adriana (2011): "Escritura como lugar de arraigo en el exilio: Tununa Mercado y María Negroni", 452 'F: Revista de Teoría de la Literatura y Literatura Comparada, n. ${ }^{\circ} 4$, pp. 92-109.

Bortignon, Martina (2013): "El sujeto enunciativo en poesía. Propuesta de un modelo de estudio", Gramma, vol. xxIv, n. ${ }^{\circ}$ 51, pp. 40-57.

Braidotti, Rosi (2003): "Becoming Woman: Or Sexual Difference Revisited", Theory, Culture \& Society, vol. 20, n. ${ }^{\circ}$ 3, pp. 43-64.

- (2005): Metamorfosis. Hacia una teoría materialista del devenir. Trad. Ana Varela Mateos. Madrid, Ediciones Akal.

Castro, Andrea (2015a): "El arte como horizonte utópico del sentir en La Anunciación", 452 F: Revista de Teoría de la Literatura y Literatura Comparada, n. ${ }^{\circ} 12$, pp. 167-181.

(2015b): "Habitando la lengua: subjetividades nómadas en la narrativa de María Negroni". En: Andrea Castro y Anna Forné (eds.), De nómades y migrantes. Desplazamientos en la literatura, el cine y el arte hispanoamericanos. Rosario, Beatriz Viterbo Editora.

Cavarero, Adriana (2005): For More than One Voice: Toward a Philosophy of Vocal Expression. Stanford, Stanford University Press.

\footnotetext{
12 En este sentido, el yo poético de Negroni nunca termina de posicionarse como lo describe Bortignon en su trabajo sobre el sujeto enunciativo en poesía: "Esto es, el sujeto socio-histórico, psicológico, fenomenológico, lingüístico y creativo puede ser un ente fracturado, explosionado, esquizoide, atravesado por pulsiones encontradas, pero, cuando se posiciona en el origen de un discurso y pronuncia 'yo', se instaura una estructura unitaria de base, un umbral, que es el dispositivo de la enunciación" (2013: 42).
} 
Chion, Michel (1999): The Voice in Cinema. Trad. Claudia Gorbman. Nueva York, Columbia University Press.

Didi-Huberman, Georges (2003): The Power of the Figure: Exegesis and Visuality in Christian Art. Umeå, Dept. of History and Theory of Art.

(2011): Lo que vemos, lo que nos mira. Trad. Horacio Pons. Buenos Aires, Manantial.

Guerrero, Juan Carlos (2010): "Los cuerpos en dolor (I): emblemática del régimen ético de la violencia", Revista de estudios sociales, n. ${ }^{\circ} 35$, pp. 123-37.

Iser, Wolfgang (1980): The Act of Reading: a Theory of Aesthetic Response. Baltimore, Johns Hopkins University Press.

Lispector, Clarice (1982): La pasión según G. H. Trad. s.n. La Habana, Casa de las Américas.

Merleau-Ponty, Maurice (1993): Fenomenología de la percepción. Trad. Jem Cabanes. Barcelona, Planeta-Agostini.

Moreno, María (2015): "María Negroni - La jaula bajo el trapo". En: Ediciones de la Palma. Accesible en <http://www.edicioneslapalma.com/novedades/193/La-jaula-bajoel-trapo> [última consulta: 14.09.2015].

Negroni, María (2007): La Anunciación. Buenos Aires, Seix Barral.

— (2009): "La felicidad de un mundo impreciso", Revista Literaria AZUL@RTE. Accesible en <http://revistaliterariaazularte.blogspot.se/2010/01/maria-negroni-la-felicidad-de-un-mundo.html> [última consulta: 24.08.2015].

(2014): La jaula bajo el trapo. Madrid, Ediciones La Palma.

Rancière, Jacques (2010): "El espectador emancipado". En: El espectador emancipado. Trad. Ariel Dilon. Buenos Aires, Manantial, pp. 9-28.

Scarano, Laura; Romano, Marcela; Ferrari, Marta (1994): La voz diseminada: hacia una teoría del sujeto en la poesía española. Buenos Aires, Editorial Biblos.

Tejeda, Isabel (2002): "Teatro: Tadeusz Kantor - La clase muerta", Enfocarte.com - Revista digital de arte y cultura. Accesible en <http://www.enfocarte.com/3.18/teatro.html> [última consulta: 15.10.2015].

Thenon, Luis (2013): "La escritura intermedial en la escena actual", Diálogos. Revista Electrónica de Historia, vol. 14, n. ${ }^{\circ}$ 2. Accesible en <http://www.redalyc.org/articulo. oa?id=43928825007> [última consulta: 15.10.2015]. 